\title{
THE ROLE OF THE KENYAN MEDIA IN THE 2007 ELECTIONS
}

\author{
Fredrick Ogenga
}

\author{
Fredrick Ogenga, an independent media consultant \\ and analyst, is a doctoral student in media studies at the \\ University of the Witwatersrand \\ e-mail: braco_od@yahoo.com
}

\begin{abstract}
This paper argues that the media occupy a central role in the advancement of democracy and should be upheld as an institution that protect democracy. The paper cites the role the Kenyan media played in the election crisis, acknowledging its success but at the same time questioning its failure to protect various aspects of democracy such as the election process. This it does by mentioning the work of various Kenyan journalists who criticised the election process through the media. The paper uses the ideal concept of democratic thought as conceptualised by the German philosopher Jürgen Habermas to examine clinically democracy in Africa and propose an alternative system of human relations as presented by the Ghanaian thinker Stephen Appiah to indicate a move to a more egalitarian society that still recognises liberal ideals.
\end{abstract}

\section{INTRODUCTION}

This paper discusses the recent political crisis in Kenya and the position of the Kenyan media following the disputed 27 December 2007 election between two main rival political parties, the Orange Democratic Movement (ODM) and the Party of National Unity (PNU). The critical question is which voices were being heard from the media and why, and the way forward for African democracy.

In an attempt to address these issues a critical approach is taken to the various theories of the press. This is looked at in the context of theories of democracy, particularly Habermas's concept of 'rethinking the public sphere' and the alternative ideas about the public sphere championed by Appiah, with a special look at his work on cosmopolitanism 


\section{THE PUBLIC SPHERE}

According to Habermas ${ }^{1}$ the public sphere is a political space created only during the electioneering period when the ruling class positions itself to convince the electorate (proletariats and bourgeoisies) through campaigns that they are fit to be their leaders.

Lucy Oriang', editor of the Daily Nation, the largest urban newspaper in Kenya, in an article dated 1 February 2008, wrote:

Only a month or so ago, this country [Kenya] was awash with posters, huge spending on billboards and a massive assault on our senses in both print and electronic media. The political parties spent billions trying to win us over to their side. We were inspired, and the turnout was more than even the most optimistic of pundits could have anticipated.

Two issues raised by this excerpt are the cultural role of the media in Kenyan society and the funding that gives politicians the power to purchase cultural capital, enabling them to contest for and win the lion's share of public space through the media.

Clearly, campaigning and advertising are costly pursuits. In the United States, for instance, according to Fox News, US President Barack Obama had raised campaign funds of \$52-million by June and his opponent, John McCain, \$21.5-million. Habermas argues that material resources give individuals the power to contest the public sphere and that, essentially, this space is dominated by the elite, who position themselves strategically and protect themselves from any form of opposition by discouraging plurality of thought.

From a classical Marxist perspective, then, this amounts to authoritarian tendencies by the ruling class, but from a post-Marxist perspective, it is a case of those who own that material resources having cultural capital and the means to buy their way into the public sphere and therefore win the consent of the majority.

In such an arrangement there is a power struggle between the elite and the bourgeoisie. Here, democracy is characterised by the possibility of encouraging some form of plurality of thought and the ability of citizens to exercise their freedom through an election process whereby they decide on the kind of leaders they want.

1 For more readings on the public sphere see Fraser 1992. 
Habermas points out that, although this process might seem liberal, it is still characterised by exclusions and limitations in that voters are left with limited options to choose from in the public sphere, given that, since most people languish in poverty, only those with material resources make it to this political space. Nevertheless, the power struggle between the bourgeoisie and the ruling class is heightened during the electioneering period, with elections forming the climax of democratic thought.

\section{BUT WHAT HAPPENS AFTER ELECTIONS?}

The president of the United States is more likely than the president of Kenya to deliver on promises made during an election campaign. However, the US president, too, inherits institutionalised state machinery (the industrial military complex built over the years by the strong foundations that define America's existence and socio-economic strategic positioning in world politics and which are unlikely to change.

In the circumstances, Obama's 'change campaign' will amount to little more than a change in the person occupying the White House and a different style of handling certain aspects of US foreign, health, education, and energy policies.

In his paper 'Rethinking the Public Sphere' (see Fraser 1992) Habermas defines the public sphere as a political arena created only during the electioneering period to create a public space to contest for power. He sees it as a very seasonal, semi-permanent, almost artificial arrangement where the so-called ruling class emerge to make promises to the bourgeoisie if elected.

\section{WHO MAKES IT TO THE 'PUBLIC SPHERE'?}

Habermas notes that wealth is a major determinant of who will achieve political success. In Third World countries as in Western countries it is mostly the rich who will succeed and voters have limited options come elections because they have only a limited group of people to choose from In Kenya, for example, the choice was between Mwai Kibaki, Raila Odinga, Kalonzo Musyoka and Uhuru Kenyatta. In order to achieve power, those who aspire to it make a multitude of promises.

Oriang' notes the following examples of promises given by Kenyan politicians during the elections by hypothetically identifying problematic issues of development and how the so-called leaders would quickly resolve them in order to garner support.

- Bad politics will inevitably breed bloodshed. Throw money into the mix, and there'll be hell to pay. So, there's tension in the teaching 
ranks and the election is just around the corner? Give them a juicy pay raise, but let it be known that it is only effective after the election That way you get to keep them on a leash.

- So the community next door is feeling that 'one of their own' is not in a high level government position? Well, give a slew of them the shadowy title of assistant minister. That will take care of the shared national resources issue, never mind that they don't really do any serious work and that they will not be sharing their pay with their constituents. Hell, no!

- As for free education, an election is hardly the right time to refer to the small print to do with class sizes and all the extra costs that come with children going to school.

- Are the long suffering people up in the north complaining about 'development' not reaching them? A handful of boreholes should do the trick. Better still, transfer some bulldozers to the district headquarters - and keep them there until after things have gone quiet. That way, they will not be asking how life is down there in Kenya.

I am sure you can find your own local examples of how cash campaigns have corrupted our politics. I will add one that is not on Oriang"s list. This one came from President Kibaki when he was still campaigning. I saw him saying it on television that there was no need for him to introduce money bearing his portrait and emphasising that he would never do so. Only weeks after the election Kibaki introduced a Sh 40 coin the economy did not need and justified it by claiming that it was a souvenir. That's when I realised that nothing has changed. I was not the only Kenyan who thought so, here is an excerpt from two Kenyan bloggers who share my view:

... When he came into power he said he will not change the currency and yet he's already done it. Kenyan presidents are all the same.

On the flip side of the coin, it has the inscription 'commemorating the 40th Anniversary of Independence'. There was a similar commemorative coin to mark the 10th anniversary of independence. That was a 10-sided 10 shilling coin. It was acceptable for payment, in the same way this one is, and was a one-off issuance. I expect that CBK will not be issuing more 40 / - coins after marking the end of these celebrations ... OO remind them of the shilingi Kumi coin. www.mashada.com 


\section{WHAT NEXT THEN FOR THE ELECTORATE?}

According to Habermas the bourgeoisie creates its own space, which he calls 'the subaltern counter publics', an attempt to resist domination by the ruling class and to topple it if need be through the formation of civil rights groups which spearhead civil disobedience, demonstrations, and strikes and sometimes create lawlessness.

In the absence of a strong civil society and workers' unions in Kenya the public took the law into its own hands, arranging demonstrations and protests. In the absence of security and order violence and crime was an obvious option.

According to Habermas, this type of action is a step towards democracy and should be permitted, but only if the demonstrations are peaceful and don't violate the human rights of any section of the population.

Among the reasons for the violent protests in Kenya was that tensions were brewing among members of different tribes, which can be related to a history of poverty and inequality. Habermas argues that in an ideal democracy there should be a multiplicity of opinions, and that different voices should be given a chance and be accommodated in an attempt to reach a common good. In addition he advocates greater equality among the citizens, though he accepts that real equality is difficult to achieve.

If we apply this to what happened in Kenya, it becomes clear that the country was moving against the grain of an ideal democracy. The government had no time for a multiplicity of opinions and made the right to demonstrate and protest illegal, thereby killing the subaltern counter public (oppositional groups such as civil and human rights groups, which are crucial in ideal democracy). The gap between rich and poor has grown under Kibaki's rule and the press has been muzzled and fundamental freedom of expression threatened by internet blogs.

\section{THE ROLE OF THE KENYAN MEDIA?}

It is well known that the media set agendas (McCombs, Shaw \& Weaver 1997; Graber 2000) and use values such as prominence (journalists quoting renowned public figures when reporting news stories) to satisfy the interests of the public. How, then, did the Kenyan media report on the crisis?

Prior to the elections the media did a tremendous job covering campaigns and providing air time and space for candidates to reach the masses. They also did well in releasing opinion polls that proved largely correct in predicting the outcome of parliamentary elections. One reason for the contested presidential election is that the media carried extensive coverage of the voting process and released unofficial results in which Kenyans believed. 
The problems arose when the official results did not match what the media had predicted. Soon after being sworn in the government banned all live broadcasting, a move that undermined freedom of the press and the very fundamental freedom of expression.

During this period of the media blackout a member of Kenya's Human Rights Watch, Maina Kiai, was quoted in an article published in The Star on 7 January 2008 and titled 'Kenyan media spurns violence and calls for peace', as saying that the Kenyan media had failed to search beneath the surface for the root causes of the political crisis.

He accused the media of suppressing the reality of what many saw as tribal cleansing related to the disputed presidential election. He continued, 'The only way to peace is through truth and justice. It's not enough to be calm; we need the truth.'

The situation raises two issues:

- One of the roles of the media is to inform, but within the boundaries of social responsibility. While they strive to report the truth by providing facts and objective accounts of events they must do so in a way that will not incite people to commit more violence.

- Tribalism is an identity problem which is aggravated by the stereotypes attached to the 'Other', whether these are negative or positive. Identity issues are ideological and one of the ways in which ideology ${ }^{2}$ thrives is through propaganda and the naming or blaming of the 'Other'. The worst cases become violent and have in them elements of tribal cleansing and genocide. The Senegalese president, addressing this year's AU summit in Ethiopia, equated the Kenyan situation with some form of genocide.

The Kenyan media abandoned the notion of commercialising ${ }^{3}$ news content for the sake of profits, avoided naming either the victims or the perpetrators of the violence, employed investigative/ critical journalism and chose to preach peace. This was a positive move, which was later to help reunify Kenya. This conduct demonstrates the maturity of the media and further proves that the Kenyan media uphold and respect their role in Kenyan society.

In any human rights issue related to two or more conflicting interest groups the rule of law anywhere in the world will defend the idea of balancing rights to see which rights outweigh others and which infringe on others. In this case,

$2 \quad$ For more on ideology see Althusser 1971.

3 For more on the economic factors that influence journalistic content see McNair 1998. 
the Kenyan media seem to have understood that the right to peace outweighed the right of Kenyans to know (freedom to receive information) which tribe was killing which and in what manner; information that would only have aggravated the situation.

However, according to Sisule F Msungu, writing from Geneva on 24 January 2008 in an unspecified publication, there are ways in which the Kenyan media failed Kenyans. Kenyans have always known the weaknesses of the Electoral Commission of Kenya (ECK) and the courts, which is why he found it necessary to examine the conduct of the media to determine what went wrong.

Msungu argues that in successive polls Kenyans have consistently ranked the media as the most trusted institution; ahead even of the church. Public institutions such as the courts and Parliament have never won the confidence of the country. He continues that while there has been intense discussion about how the international media reported the post-election violence there has been little discussion about how the local media handled the situation. The media could, and should have provided credible and useful information about the issues and numbers in the disputed constituencies.

Msungu notes that the media also failed to appreciate the importance of the dispute, and reduced it to a two-man affair, which he describes as the 'it depends on Kibaki and Raila approach'. He questions why the Kenyan media failed to play the role of watchdog by using the publicly announced results at polling and constituency level to ensure that there was no fiddling or allegation of fiddling.

Hours before the ECK declared Kibaki the winner, it was clear that the mainstream media - with their extensive network - had possession of most, if not all, the publicly announced results and could therefore independently come up with the tally.

He ends the article by claiming that both the Daily Nation, on its website, and the Kenya Television Network (KTN) did, in fact, display advance figures on 30 December, before suddenly withdrawing the figures. According to him, The Daily Nation's figures showed Odinga with more than 4,5-million votes and Kibaki with just over 4,2-million. ${ }^{4}$ Why, he asks, did they withdraw these figures?

\section{IS DEMOCRACY ALL ABOUT ELECTIONS?}

In view of the drama surrounding the Kenyan elections one might question the meaning of democracy. Democracy, ideally, simply means the freedom to elect the

4 See also Barkan 2008 and Barkan's update of his January / February 2004 essay 'Kenya after Moi'. 
leader of the majority's choice without fear of intimidation. In the United States democracy goes hand in hand with the first amendment to the Constitution, which concerns freedom of expression.

According to Habermas there is no such thing as democracy. However, he believes that any move towards an ideal democracy would have to encompass greater equality among citizens.

In an article entitled 'Kenya's crisis and challenges of democracy in Africa' (www.alainkanyinda.net 9 February 2008) Nyaga Munyi expressed the belief that Africa's democratic honeymoon is rapidly drawing to a close and Kenya's sudden drift into chaos is a wake-up call for a more concerted investment in governance programmes on the continent as a whole.

After a decade of democratic gains Africa now finds itself in a swamp, with Nigeria, Kenya, and even South Africa facing defining moments. The next five years will mark a watershed in the continent's democratic consolidation. Munyi claims that the violence in Kenya caused by political discontent brings into sharp focus the challenges of democracy in Africa and the need for heterodoxy in political governance among African governments and institutions working 'to promote democracy' on the continent.

The situation in Kenya, he continues, exposes the fragile nature of the country's democracy and points to the role the international community should play in developing African politics, which, like its music, moves in sweeping waves.

Democratic disillusionment has produced two major trends in African politics - the ethnic and the socialist appeals - which will complicate the continent's democratic development in the next decade. These trends, he concludes, reflect responses to a sense of economic exclusion, where ordinary people feel political institutions do not respond appropriately to their problems. This is best demonstrated by events in the three African 'pillar' countries - South Africa, Nigeria and Kenya. The recent elections in Kenya and Nigeria highlight an ethnic appeal.

In Kenya the government has a difficult task and a long and rugged road to travel.

- It must leave the media alone.

- It must ensure that Kibera, the biggest slum in Africa, and other slums in the country, are eradicated.

- It must allow the opposition to stage peaceful protests and include the opposition's agenda in the country's Constitution. 
Although the second of these tasks is unlikely to be completed any time soon, in relation to the last the government of national unity should ensure there are some radical shifts in the way the institutions that defend democracy - the legislature, the judiciary and the media - operate through constitutional amendments that are already taking shape.

\section{WHAT NEXT FOR KENYA AND DEMOCRACY IN AFRICA?}

In his work on cosmopolitanism Stephen Appiah (2007) writes about a situation in which people, driven by shared values, do not regard each other as strangers ('othering'). This ideal can be advanced by media interaction, especially through new media such as internet blogs and sites where people can interact in an effort to reach a common goal. No wonder Kenyans kept the world informed through internet blogs when a 'state of emergency' was declared and President Kibaki and his Mt Kenya henchmen banned all live broadcasts at the height of the postelection violence.

Africa appears to be the wrong context in which to practise the Western concept of democracy. Africa must distinguish between democracy as a means and democracy as a goal. There are four fundamental goals of democracy: to make rulers accountable and answerable for their actions and policies; to make citizens effective participants in choosing those rulers and in regulating their actions; to make the society as open and the economy as transparent as possible; and to make the social order fundamentally just and equitable (Mazrui 2002).

The first challenge is, therefore, how to achieve these goals in a manner that is appropriate to Africa (Obioma 2001). The second challenge to democracy in Africa concerns its relationship to development. One persistant question in this regard is 'is Africa underdeveloped because it is primarily undemocratic? Or is Africa undemocratic because it is primarily underdeveloped?'

There is a third dimension, which is often treated either as part of the package of development or as part of the package of democracy, when in fact it should be treated as a kind of independent variable. This dimension is stability - a socialpolitical precondition for both sustainable development and durable democracy. Africa's three greatest needs are development, democracy and stability - but not necessarily in that order. Alleviation of poverty is one of the fruits of democratised development and one of the gains when democracy and development are jointly stabilised and truly humanised (Mazrui 2002). Stability also means creating an enabling environment to produce wealth.

Professor Ali Mazrui (2002), questioning how Africa has fared in these areas of development, democratisation, stabilisation and the alleviation of poverty explores what the words mean. In relation to development he argues 
that economists naturally focus on issues like resource flows, levels of economic diversification, domestic mobilisation of savings and investment, national productivity and per capita income (see also Mookjerjee \& Ray 2001; Ghosh 2001; Hayami 2001).

Yet high levels of performance in those areas are achieved only after other elements of development have been measured. The most crucial may be partly cultural rather than purely economic. Development in promoting performance and mobilisation of domestic savings and investment capital may need to be preceded by development in areas such as the enhancement of managerial skills, transformation of gender relations, redefinition of the work ethic as a discipline of the education system, redefinition of the laws and rules about corruption to make them more culturally viable, and reform of Africa's schools and universities to make them more skills and culturally relevant. In a paper for the World Bank, former University of Liberia president Mary Sherman (1993) sets out the obstacles and some approaches to reforming higher education in Africa (see also Mungazi \& Walker 1997).

Mazrui further argues that structural adjustment has never been the primary economic problem in Africa - that has always been how to carry out cultural readjustment. Such a readjustment would not be a demotion of African culture, it would merely result in a better balance between the continuities of African culture and Africa's borrowing from Western culture.

Until now African has acquired Western tastes without Western skills; Western consumption patterns without Western production techniques; urbanisation without industrialisation; secularisation (erosion of religion) without scientification. Would Africa have been better off if it had retained its own tastes while borrowing Western skills - instead of absorbing Western tastes and retaining its own lower levels of skills? Would Africa have been better off with African consumption patterns and Western production techniques instead of the other way round?

Ultimately, the media in Kenya, and in Africa in general, have played an increasingly significant role in the advancement of the society by providing a platform for consensus on various contentious issues facing the continent. They have done this by educating and informing the public about various important issues. They also act as a cultural carrier of a society's way of life, ensuring that African culture is sustained in the face of a Western-dominated way of life. Most of the media operating in Africa have a local content policy which ensures that the abundance of Western concepts is ameliorated by a specified percentage of locally relevant information.

Unfortunately, the role played by the media in most countries in Africa has been undermined by political ambition and journalistic integrity has frequently 
been sacrificed on the altar of commercial interests and profits. However, many political regimes in Africa are becoming increasingly tolerant of criticism from the media and acknowledge the watchdog function of the media as a necessary step and a prerequisite for the media's existence in a so-called liberal democracy. This change in attitude is desperately needed if Kenya and other African countries are to move towards the ideal concept of democracy conceptualised by Habermas.

\section{- REFERENCES}

Althusser, L. 1971. 'Ideology and ideological state apparatuses'. In Lenin and Philosophy and Other Essays. London: New Left Books.

Appiah K A. 2007. Ethics in a world of strangers. London, New York: Penguin Books Limited.

Barkan, J D. 2004. 'Kenya After Moi'. Foreign Affairs online, 1 January 2004.

Fraser, N. 1992. 'Rethinking the Public Sphere: A Contribution to the Critique of Actually Existing Democracy'. In C Calhoun (ed). Habermas and the Public Sphere. Cambridge, MA: MIT Press.

Ghosh, B N. 2001. Contemporary Issues in Development Economics. London and New York: Routledge.

Graber, D A. 2000. Media Power in Politics. Washington, DC: CQ Press.

Gramsci, A. 1971. The Prison Notebooks. London: Lawrence and Wishart.

Hayami, Y. 2001. Development Economics: From the Poverty to the Wealth of Nations. Oxford and New York: Oxford University Press.

Mazrui, A. 2002. Who killed Democracy in Africa? Binghamton: Institute of Global and Cultural Studies.

McCombs, M, L Shaw \& D Weaver. 1997. Communication and Democracy: Exploring the Intellectual Frontier in Agenda Setting Theory. Mahwa, NJ: Lawrence Erbaum Associates.

McNair, B. 1998. The Sociology of Journalism. London: Arnold.

Mookjerjee, D \& D Ray (eds). 2001. Readings In The Theory Of Economic Development. Malden, MA: Blackwell Publishers.

Mungazi, D A \& L K Walker. 1997. Educational Reform and the Transformation of Southern Africa. Westport, CT: Praeger.

Obioma M (ed). 2001. Contending Issues in African Development: Advances, Challenges, and The Future. Westport, CT : Greenwood Press.

Sherman, M A B. 1993. Building Consensus for Higher Education Reform in Africa: Some Reflections. Washington, DC: World Bank, May. 